\title{
A REVIEW OF 2015 LAWYER DisCiPline MATTERS
}

\author{
G. Michael Witte*
}

\section{INTRODUCTION}

The attention-grabbing aspect of per curiam lawyer discipline opinions issued by the Indiana Supreme Court in 2015 centered more on the punishment imposed upon the lawyer rather than any new developments in, or interpretations of, the Indiana Rules of Professional Conduct. Four disbarments were handed down in the timespan of this article (October 1, 2014 to September 30, 2015). ${ }^{1}$ Additionally, another lawyer barely escaped disbarment on a 3-2 vote of the justices. $^{2}$ In another matter, a Missouri lawyer, who also maintained an Indiana license, was disbarred by Illinois authorities. ${ }^{3}$ Indiana imposed reciprocal discipline but not a full disbarment. ${ }^{4}$ Instead, the Indiana Supreme Court suspended the lawyer's license indefinitely. ${ }^{5}$

For Indiana lawyers, the sanction of disbarment is permanent. ${ }^{6}$ It is the death penalty to one's legal career. ${ }^{7}$ One can never reinstate his law license after disbarment. ${ }^{8}$ This is not the case in all U.S. jurisdictions. ${ }^{9}$ For example, a disbarred Illinois lawyer retains the ability to seek reinstatement to the bar after serving five years of the disbarment. ${ }^{10}$

In the two-year span from July 2013 through July 2015, seven ${ }^{11}$ Indiana lawyers received the ultimate sanction from the Indiana Supreme

* Executive Secretary, Indiana Supreme Court Disciplinary Commission; J.D., 1982, Indiana University Robert H. McKinney School of Law. The opinions expressed herein are solely those of the author and do not represent a statement of law or policy by the Indiana Supreme Court, its staff, or attendant agencies or organizations. The author thanks law clerk Darwinson Valdez for his research assistance in the creation of this work.

1. See In re Ouellette, 37 N.E.3d 490, 491 (Ind. 2015); In re Stochel, 34 N.E.3d 1207, 1208 (Ind. 2015); In re Hamilton, 34 N.E.3d 1204 (Ind. 2015); In re Keaton, 29 N.E.3d 103, 104 (Ind. 2015).

2. See United States v. Philpot, 733 F.3d 734, 738 (7th Cir. 2013).

3. See James J. Grogan, Attorney Regulations Summaries Supreme Court of Illinois January Term, LinCOLN DAILY News (Jan. 2015), http://archives.lincolndailynews.com/2015/ Jan/23/images/012315pics/012315\%20MAINLIB.pdf [https://perma.cc/6QVY-8T7P].

4. Id.

5. $I d$.

6. InD. R. Admis. B. \& Disc. AtT'Y $23 \S 3(\mathrm{a})$.

7. Id.

8. $I d$.

9. See, e.g., ILl. Sup. Ct. R. 767(a).

10. Id.

11. See In re Geller, 9 N.E.3d 643 (Ind. 2014); In re Haigh, 7 N.E.3d 980 (Ind. 2014); In re Smith, 991 N.E.2d 106 (Ind. 2013). These are Disbarment cases occurring in this timespan, but not addressed in this Article. The Orders and Opinions Regarding Final Resolution in Attorney Disciplinary Cases can be found on the Indiana Supreme Court website.

http://dx.doi.org/10.18060/4806.01123 
Court—-permanent disbarment. ${ }^{12}$ This is a significant number when compared to the ten years prior to July 2013: in that decade-long span, a total of eight lawyers were disbarred. ${ }^{13}$ This Article will review the four disbarments as well as the two near-disbarments that occurred in the current reporting period.

\section{IN RE KEATON}

The Keaton matter gained quick notoriety for the scandalous facts underlying the misconduct. Some critics questioned whether the Disciplinary Commission brought this case solely because of the prurient nature of the facts. Much of the criticism is based on the question of what connects a lawyer's personal misconduct to his or her ability to practice law. That debate will be addressed later in this segment.

In 2005, attorney R. Mark Keaton, then forty-one years old, married, and living in Fort Wayne, began an intimate relationship with J.D., a sophomore at Indiana University and the roommate of his daughter. ${ }^{14}$ For nearly three years, the relationship vacillated between emotional, volatile, passionate, turbulent, and exploitive. ${ }^{15}$ J.D. permanently ended the long-distance relationship in March 2008 - or so she thought. ${ }^{16}$ For the next four months, respondent harassed J.D. with numerous voicemails, ninety of which she was able to record and preserve for evidentiary purposes. ${ }^{17}$ For two years following the break-up, Keaton and J.D. exchanged at least 7199 emails, the vast majority being sent by Keaton. ${ }^{18}$ All of the communications "were threatening, abusive, and highly manipulative in nature." 19

The tone and content of the various communications is illustrated by the following excerpt from the court's opinion:

One illustrative example among the many similar voicemails left by

Respondent and preserved by JD is the following:

(Shouting) Call me the $\mathrm{f}^{* * *}$ back! I don't know who the $\mathrm{f}^{* * *}$ you think

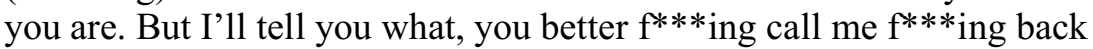
now! You $\mathrm{f}^{* * *}$ with me one more time and this time you'll really $\mathrm{f}^{* * *}$ ing pay for it! And you need to think about it! Now you $\mathrm{f}^{* * * i n g}$ quit

12. See In re Steele, 45 N.E.3d 777 (Ind. 2015). On December 1, 2015, the court disbarred another attorney for misconduct. However, that case is outside the reporting period of this Article.

13. In re Smith, 991 N.E.2d 106; In re Patterson, 969 N.E.2d 593 (Ind. 2012); In re Mendenhall, 959 N.E.2d 254 (Ind. 2012); In re Rawls, 936 N.E.2d 812 (Ind. 2010); In re Sniadecki, 924 N.E.2d 109 (Ind. 2010); In re Lehman, 901 N.E.2d 1097 (Ind. 2009); In re Powell, 894 N.E.2d 519 (Ind. 2008); In re Davidson, 814 N.E.2d 266 (Ind. 2004).

14. In re Keaton, 29 N.E.3d 103, 104 (Ind. 2015).

15. Id.

16. Id.

17. Id.

18. Id.

19. Id. 


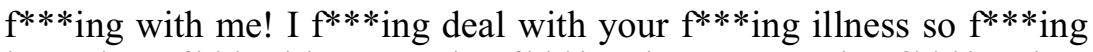
long, don't $\mathrm{f}^{* * *}$ with me another $\mathrm{f}^{* * *}$ ing day! Not another $\mathrm{f}^{* * *}$ ing day! You return my call right now!

We agree with the hearing officer's assessment that "[ $[\mathrm{t}] \mathrm{he}$ true angry, hostile and threatening content and tone present in the voicemails can only be fully understood” by listening to them. (HO's Report at 920 ). Quite simply, they are profoundly disturbing. ${ }^{20}$

Keaton's threats included suicide, physical, and economic harm towards J.D., and public embarrassment for J.D. ${ }^{21}$ He carried out the last threat. ${ }^{22}$ Keaton publicly disseminated compromising photographs of J.D. taken during the relationship. ${ }^{23}$ He sent them to J.D.'s family and friends, and posted them on adult-oriented websites. ${ }^{24}$ Keaton also maintained and published a blog about J.D. for several years where the explicit photographs were also posted. ${ }^{25}$ On the days of Keaton's discipline trial, he still refused to terminate the blog or delete the photos. ${ }^{26}$

Other acts of Keaton's post-break-up obsessive harassment included:

- Stalking J.D. on campus;

- Peeking in her apartment windows;

- Confronting J.D. in a student lounge;

- Hiring a private investigator to discover a new phone number obtained by J.D.; and

- Using seventeen different email addresses and at least one fake social media profile in order to overcome JD's ability to block communications. ${ }^{27}$

In August 2009, J.D. initiated legal action against Keaton, both civil and criminal. ${ }^{28}$ This only caused Keaton to escalate his harassment. ${ }^{29}$ Keaton's provocation continued through February 2012 when Keaton was notified the Disciplinary Commission was investigating his conduct. ${ }^{30}$ Ten days later, Respondent filed a pro se civil complaint in state court against J.D. for malicious prosecution and abuse of process. ${ }^{31}$ Less than three months later, Keaton filed a second pro se complaint in federal court against J.D. and law enforcement

20. Id. at $104 \mathrm{n} .1$.

21. Id. at 105 .

22. Id.

23. $I d$.

24. Id.

25. Id. at 106 .

26. Id. at 105 .

27. Id. at 106.

28. Id. at 107.

29. Id.

30. Id.

31. Id. 
authorities for unlawful arrest. ${ }^{32}$

In his response to the Commission's inquiry, Respondent stated,

Throughout all the prosecutions, [Respondent] has tried not to disparage [JD] nor has he even suggested that [JD] has been less than truthful with the various law enforcement and attorneys with whom she has communicated. As far as [Respondent] can remember, he's never suggested that [JD] has lied to anyone. Put simply, [Respondent] doesn't know whether she has or hasn't, because she has never testified in any proceeding relating to these matters nor has she ever been required to provide any kind of factual support under oath for the facts that others keep asserting. ${ }^{33}$

This response was in direct contradiction to the amended complaint filed in the federal civil suit. ${ }^{34}$ Keaton alleged J.D. and others provided false information, testimony, and evidence in the criminal investigation. ${ }^{35}$

J.D. was never Keaton's client. ${ }^{36}$ The relationship began as a consensual one. ${ }^{37}$ The actions that served as the basis for Keaton's discipline did not primarily arise from the practice of law. ${ }^{38}$ So what is the nexus between Keaton's actions and his ability to practice law? Should a lawyer's actions outside the practice of law serve as a basis for sanctions against one's law license?

The Preamble to the Indiana Rules of Professional Conduct addresses this topic..$^{39}$ In addressing a lawyer's responsibilities, the Preamble acknowledges that "there are Rules that apply to lawyers who are not active in the practice of law or to practicing lawyers even when they are acting in a nonprofessional capacity." ${ }^{40}$ Additionally, the Preamble addresses a lawyer's duty to conform to the requirements of the law both in the lawyer's business and personal affairs. ${ }^{41}$

\section{Id.}

33. Id.

34. Id. at 107-08.

35. Id. at 107.

36. Id. at 109-10.

37. Id. at 104 .

38. Id. at 110 .

39. See generally Ind. PROF'L CONDUCT pmbl.

40. See id. $\$ 3$ ("In addition to these representational functions, a lawyer may serve as a thirdparty neutral, a nonrepresentational role helping the parties to resolve a dispute or other matter. Some on these Rules apply directly to lawyers who are or have served as third-party neutrals. See, e.g., Rules 1.12 and 2.4. In addition, there are Rules that apply to lawyers who are not active in the practice of law or to practicing lawyers even when they are acting in a nonprofessional capacity. For example, a lawyer who commits fraud in the conduct of a business is subject to discipline for engaging in conduct involving dishonesty, fraud, deceit, or misrepresentation. See Rule 8.4.”).

41. See id. I 5 ("A lawyer's conduct should conform to the requirements of the law, both in professional service to clients and in the lawyer's business and personal affairs. A lawyer should use the law's procedures only for legitimate purposes and not to harass or intimidate others. A lawyer should demonstrate respect for the legal system and for those who serve it, including judges, other 
The court noted lawyers must "be of good moral character and fitness" have a responsibility to conform "to the standards imposed by the law, the oath of attorneys, and our professional conduct rules." ${ }^{42}$ The court presses Keaton's behavior fell "woefully short of these standards and reflects a fundamental betrayal of the trust that has been placed in him.",43

Keaton's victimization of J.D. was found to violate the Rules of Professional Conduct. ${ }^{44}$ His acts were found to be criminal in nature - specifically the crimes of stalking, harassment, and intimidation. ${ }^{45}$ This finding supported a violation of Indiana Rules of Professional Conduct 8.4(b), which prohibits a lawyer from committing criminal acts that reflect adversely on the lawyer's honesty, trustworthiness, or fitness as a lawyer. ${ }^{46}$ Additionally, Keaton's false statements during the Commission's investigation - never asserting J.D. lied to anyone or acted less than truthful-were found to violate Indiana Rules of Professional Conduct $8.4(\mathrm{c}) .^{47}$ This rule prohibits a lawyer from engaging in conduct involving dishonesty, fraud, deceit, or misrepresentation. ${ }^{48}$ Neither of these rules restrict the scope of misconduct to occurrences within the practice of law or within a professional capacity. Both of these rules are applicable to the private behavior of a lawyer. ${ }^{49}$

Truth and honesty are cornerstones of the legal profession, both in the performance of the lawyer, and the end product pursued. Therefore, it is incumbent upon lawyers to refrain from dishonest, deceitful, or untruthful conduct. Indiana Rule of Professional Conduct 8.4(c) prohibits a lawyer from engaging in conduct involving dishonesty, fraud, deceit, or misrepresentation..$^{50}$ This rule contains no requirement the misconduct occur strictly within the course

lawyers and public officials. While it is a lawyer's duty, when necessary, to challenge the rectitude of official action, it is also a lawyer's duty to uphold legal process.").

42. In re Keaton, 29 N.E.3d at 110 (citing Baker v. Keisker, 142 N.E.2d 432, 434 (1957)).

43. $I d$.

44. Id. at 111. In a separate count, Keaton was also charged with neglecting a client. Id. at 108. Keaton failed to meet filing requirements in the client's appeal which resulted in a dismissal of the appeal. $I d$. at 109-10. Keaton then failed to notify the client of the dismissal. Id. These omissions were found to violate Indiana Professional Conduct R. 1.4(a)(2), for failing to "reasonably consult with a client about the means by which the client's objectives are to be accomplished," Rule 1.4(a)(3): for failing to "keep a client reasonably informed about the status of a matter," and Rule 1.4(b) for failing to "explain a matter to the extent reasonably necessary to permit a client to make informed decisions regarding the representation." Id. at 108. The academic discussion of the importance of the Keaton case is focused solely on the personal misconduct of the lawyer.

45. Id. at 109 .

46. Id.

47. Id. at 110 .

48. Ind. Prof'L CONDUCT R. 8.4(c).

49. Ind. PRof'L CONDUCT R. 1.4, 8.4.

50. Ind. Prof'L CONDUCT R. 8.4(c). 
of the practice of law or in a professional capacity. ${ }^{51}$ Nevertheless, the fact that this particular instance of untruthfulness occurred in a legal proceeding would fulfill a nexus requirement if one existed. ${ }^{52}$ Keaton was unanimously disbarred for his misconduct. ${ }^{53}$

\section{IN RE HAMILTON}

Bradley D. Hamilton was disbarred in 2015 for misconduct that involved abandonment of his law practice and clients, stealing their money and fleeing to Australia. ${ }^{54}$ Hamilton never responded to the formal complaint filed by the Disciplinary Commission and was disbarred on a Judgment on the Complaint. ${ }^{55}$

Hamilton abruptly abandoned his law practice and moved to Australia in September $2013 .^{56} \mathrm{He}$ had collected more than twenty retainer fees from clients before leaving Indiana.$^{57} \mathrm{He}$ did little or no work on many of these cases and failed to refund unearned portions of the fees. ${ }^{58}$ He neglected many of these clients by being unresponsive to inquiries and lying about the status of some of their cases. ${ }^{59}$ In two matters, Hamilton falsely told the clients he had filed their bankruptcy petitions.$^{60}$ In three other non-bankruptcy civil matters, Hamilton made similar false claims about case filings. ${ }^{61}$ In several instances he took on new clients and accepted retainer fees while his move to Australia was imminent. ${ }^{62}$ Furthermore, when Hamilton departed for Australia, he failed to leave behind any records indicating from which client's or clients' money was collected, disbursed, or retained. ${ }^{63}$

51. See, e.g., IND. Prof'L CONDUCT R. 4.1-4.4. For comparison, a nexus requirement is present in other rules of professional conduct. These rules are applicable to transactions with persons other than clients. Each of these rules use language that restricts application to actions in the course of representing a client. See also IND. PROF'L CONDUCT R. 8.4(g) (governing conduct of bias or prejudice but limiting application to conduct occurring "in a professional capacity").

52. See, e.g., In re Dempsey, 986 N.E.2d 816 (Ind. 2013) (providing other examples of the professional conduct rules being applied to personal actions, specifically misconduct arising from Dempsey's personal bankruptcy and personal real estate foreclosure); see also In re Usher, 987 N.E.2d 1080 (Ind. 2013) (detailing misconduct arising from Usher's rejected pursuit of a relationship with a legal intern); In re Herthel, 760 N.E.2d 155 (Ind. 2001) (discussing misconduct arising from Herthel's involvement in a traffic collision).

53. In re Keaton, 29 N.E.3d 103, 104 (Ind. 2015).

54. In re Hamilton, 34 N.E.3d 1204 (Ind. 2015).

55. Id.; see also, InD. R. Admis. B. \& Disc. ATT'y $23 \S 14(\mathrm{c})$.

56. In re Hamilton, 34 N.E.3d at 1205.

57. Id.

58. Id. at 1206 .

59. Id. at 1207.

60. Id. at 1205 .

61. Id.

62. Id. at 1205-06.

63. Id. at 1206 . 
This case is somewhat short in academic discussion of the various ethics violations. Hamilton's lack of participation in the discipline proceedings ${ }^{64}$ and eventual default eliminated a cause for debate. However, this case serves as a lesson about a lawyer's ethical obligations when winding down a law practice. Practice management should include maintaining client files, trust accounts, and fee payment records. ${ }^{65}$ When terminating a law practice, clients should be "notified and kept fully and accurately informed of matters relating to their case." ${ }^{\prime 66}$ A contingency plan should be in place to transition the clients' cases to successor lawyers. ${ }^{67}$

Within Rule 23 of the Indiana Rules for Admission to the Bar and the Discipline of Attorneys, Section 27 is a comprehensive rule known as the "Attorney Surrogate Rule." ${ }^{68}$ It is designed specifically for the moment of termination of a solo law practice. ${ }^{69}$ This Rule is not intended for a partnershiporiented law practice, because there is a surviving firm or partner(s) to pick up for the career-ending lawyer. In the partnership setting, the move to successor counsel, and the attendant record management duties, should be seamless. In summary, an attorney surrogate is not substitute counsel for the departing lawyer. The attorney surrogate merely takes on a role of being a custodian to gather client files and financial records, give notice to the client base, disburse files, and make referrals to successor counsel. The attorney surrogate might also communicate with courts to get brief reprieves from any impending hearings or deadlines.

Hamilton enlisted an attorney surrogate two days before leaving for Australia. ${ }^{70}$ However, the surrogate was not prepared for the onslaught of misdeeds that were quickly exposed upon Hamilton's exit. ${ }^{71}$ Hamilton's misconduct included violations of the following Rules of Professional Conduct:

[Rule] 1.3: Failure to act with reasonable diligence and promptness.

[Rule] 1.4(a)(3): Failure to keep a client reasonably informed about the status of a matter.

[Rule] 1.4(a)(4): Failure to comply promptly with a client's reasonable requests for information.

[Rule] 1.4(b): Failure to explain a matter to the extent reasonably necessary to permit a client to make informed decisions.

[Rule] 1.16(d): Failure to protect a client's interests upon termination of representation, and failure to refund an unearned fee promptly upon termination of representation.

[Rule] 8.4(b): Committing a criminal act (conversion or theft) that

64. Id. at 1205 .

65. Id. at 1206 .

66. Id.

67. Id.

68. InD. R. Admis. B. \& Disc. AtT'y 23 § 27.

69. See id.

70. In re Hamilton, 34 N.E.3d at 1205.

71. Id. at 1206. 
reflects adversely on the lawyer's honesty, trustworthiness, or fitness as a lawyer.

[Rule] 8.4(c): Engaging in conduct involving dishonesty, fraud, deceit, or misrepresentation.

[Rule] 8.4(d): Engaging in conduct prejudicial to the administration of justice. $^{72}$

\section{IN RE STOCHEL}

Attorney Robert E. Stochel was another attorney disbarred for thievery. ${ }^{73} \mathrm{He}$ embezzled from a receivership he was appointed to oversee and stole liberally from a former law partner's trust account. ${ }^{74}$ Similar to Bradley Hamilton, ${ }^{75}$ Stochel also failed to participate in his discipline proceeding and judgment was granted summarily on the complaint. ${ }^{76}$

Stochel was appointed as a receiver of a jointly owned grocery store which was involved in a legal dispute. ${ }^{77}$ Around 2002, Stochel began withdrawing funds from a receivership account for personal use and without authority to do so. ${ }^{78} \mathrm{By}$ 2004 , the account had been completely depleted of about $\$ 330,000 .^{79}$ Stochel then would deposit personal funds into the account when needed to pay routine expenses for the receivership. ${ }^{80}$ The deposits and payments also served to mislead others into believing the receivership had cash and was being properly managed. ${ }^{81}$

In 2005, the beneficiaries of the receivership settled their dispute under the mistaken fact the receivership had about $\$ 330,000$ in cash. ${ }^{82}$ For the next five years, Stochel was able to hold at bay the beneficiaries and the trial court overseeing the receivership with delay tactics, false statements, and false accountings. ${ }^{83}$ In 2012, Stochel resisted the trial court's order to surrender the receivership file to an accountant ${ }^{84}$ Eventually, Stochel was cited for contempt, failed to appear at his contempt hearing despite having knowledge of the setting, ${ }^{85}$ had a warrant issued for his arrest, was jailed for contempt, and was

72. Id. (citing Ind. Prof'L CONDUCt R. 1.3, 1.4(a)(3)-(4), 1.4(b), 1.16(d), 8.4(b)-(d)).

73. In re Stochel, 34 N.E.3d 1207, 1208 (Ind. 2015).

74. Id.

75. In re Hamilton, 34 N.E.3d at 1205.

76. IND. R. ADMIS. B. \& Disc. ATT'Y Rule 23 § 14(c); see also In re Stochel, 34 N.E.3d at 1208.

77. In re Stochel, 34 N.E.3d at 1208.

78. Id.

79. Id.

80. Id.

81. Id. at $1208-09$.

82. Id. at 1209 .

83. Id.

84. Id.

85. When asked in a deposition why he ignored the contempt hearing, Stochel replied that 
removed as the receiver. ${ }^{86}$

At the time of the discipline proceedings, Stochel owed the receivership at least $\$ 230,000 .{ }^{87}$ Also, the beneficiaries spent $\$ 50,000$ towards reconstruction of the receivership's finances. ${ }^{88}$

In July 2012, the Disciplinary Commission began an investigation into the matter. ${ }^{89}$ For over two years, Stochel stymied the investigation through noncooperation including lying to Commission inquiries, failing to respond to Commission inquiries, failing to bring records to a deposition, and failing to appear at a subsequent deposition..$^{90}$ The Commission initiated six separate show cause actions against Stochel because of his non-cooperation. ${ }^{11}$ Stochel's web of deceit and dishonesty to the receivership beneficiaries, their respective counsel, the trial court, and the Commission allowed his misconduct to prevail for over twelve years. ${ }^{92}$

An independent episode of theft occurred when Stochel stole from his law practice associate Thomas Hoffman. ${ }^{93}$ They maintained a joint trust account in which funds of their respective clients were held..$^{94}$ As of November 3, 2011, the trust account contained almost $\$ 33,000 .{ }^{95}$ Slightly less than $\$ 5600$ in the account belonged to Stochel or his clients. ${ }^{96}$ Nevertheless, on that date, Stochel drafted a check for $\$ 30,000$ payable to himself and never repaid Hoffman for the deficiency. ${ }^{97}$

Stochel's trail of misconduct was lengthy, both in time span and number of acts. ${ }^{98}$ This resulted in findings that he violated the following multitude of Indiana Rules of Professional Conduct:

1.5(a): Making an agreement for, charging, or collecting an unreasonable fee.

he "was at home consuming gin." Verified Complaint 9 92, In re Stochel, 34 N.E.3d 1207 (Ind. 2015) (No. 45S00-1412-DI-738).

86. In re Stochel, 34 N.E.3d at 1209.

87. Id.

88. Id.

89. Id.

90. Id.

91. Id.

92. Id. at 1208 (noting Stochel's malfeasance began approximately in 2002 when Stochel embezzled funds in his role as a receiver of a jointly owned supermarket).

93. Id. at 1209.

94. Id.

95. Id.

96. Id.

97. Id.; see also Verified Complaint, supra note 85, \ 120-38.

98. In re Stochel, 34 N.E.3d at 1208, 1211 (noting Stochel's misdeeds occurred over a period of twelve years and included embezzling hundreds of thousands of dollars, impeding the Commission's investigation of his actions, and making no effort to make restitution). 
1.15(a): Failure to hold property of clients properly in trust; failure to safeguard property of clients ...

1.15(d): Failure to deliver promptly to clients and third parties funds they are entitled to receive and failure to render promptly a full accounting of those funds.

1.16(d): Failure to refund an unearned fee promptly upon termination of representation.

3.3(a)(1): Knowingly making false statements of fact or law to a tribunal or failing to correct false statements of material fact or law previously made to the tribunal by the lawyer.

3.4(c): Knowingly disobeying court orders.

4.1(a): Knowingly making a false statement of material fact to a third person in the course of representing a client.

8.1(b): Knowingly failing to respond to a lawful demand for information from a disciplinary authority.

8.4(b): Committing criminal acts (conversion, theft, deception, and criminal mischief) that reflect adversely on the lawyer's honesty, trustworthiness, or fitness as a lawyer.

8.4(c): Engaging in conduct involving dishonesty, fraud, deceit, or misrepresentation. ${ }^{99}$

The supreme court walked through the American Bar Association's (ABA) Standards for Imposing Lawyer Sanctions in determining the appropriate sanction for Stochel's multiple violations and attitude towards the discipline process. ${ }^{100}$ The court directly incorporated into its opinion the following ABA standards:

4.11 Disbarment is generally appropriate when a lawyer knowingly converts client property and causes injury or potential injury to a client. $\cdots$

4.61 Disbarment is generally appropriate when a lawyer knowingly deceives a client with the intent to benefit the lawyer or another, and causes serious injury or potential serious injury to a client. ...

99. Id. at 1210 (citing Ind. Prof'L CONDUCT R. 1.5(a), 1.15(a), 1.15(d), 1.16(d), 3.3(a)(1), 3.4(c), 4.1(a), 8.1(b), 8.4(b)-(c)).

100. Id. at 1210-11. 
5.11 Disbarment is generally appropriate when:

(a) a lawyer engages in serious criminal conduct a necessary element of which includes intentional interference with the administration of justice, false swearing, misrepresentation, fraud, extortion, misappropriation, or theft ... or

(b) a lawyer engages in any other intentional conduct involving dishonesty, fraud, deceit, or misrepresentation that seriously adversely reflects on the lawyer's fitness to practice....

6.11 Disbarment is generally appropriate when a lawyer, with the intent to deceive the court, makes a false statement, submits a false document, or improperly withholds material information, and causes serious or potentially serious injury to a party, or causes a significant or potentially significant adverse effect on the legal proceeding. ...

6.21 Disbarment is generally appropriate when a lawyer knowingly violates a court order or rule with the intent to obtain a benefit for the lawyer or another, and causes serious injury or potentially serious injury to a party or causes serious or potentially serious interference with a legal proceeding. ${ }^{101}$

The court laid out a clear justification for Stochel to be permanently disbarred through its recitation of the ABA sanction standards. ${ }^{102}$

\section{IN RE OUELLETTE}

The primary misconduct by attorney Steven J. Ouellette which caused his disbarment was his conversion of $\$ 8,725.35$ from a client.$^{103}$ Ouellette aggravated his situation by not cooperating with the discipline investigation and being delinquent in filing an answer to the verified complaint for discipline. ${ }^{104}$ Additionally, Ouellette had two prior sanctions for misconduct, which likely also served to aggravate his sanction. ${ }^{105}$

In December 2010, Ouellette received from a bankruptcy trustee a refund check on behalf of his bankruptcy clients. ${ }^{106} \mathrm{He}$ fraudulently endorsed the check, deposited it into a personal account that was not a lawyer trust account, and

101. ABA STANDARDS FOR IMPOSING LAWYER SANCTIONS (1992).

102. In re Stochel, 34 N.E.3d at 1210-11.

103. In re Ouellette, 37 N.E.3d 490, 491 (Ind. 2015).

104. Id.

105. Id. at 491 n.2; see also In re Ouellette, 636 N.E.2d 1251, 1253 (Ind. 1994) (suspending Ouellete for "knowingly ma[king] false statements of material facts to a tribunal and fail[ing] to disclose such facts when disclosure was necessary"); In re Ouellette, 857 N.E.2d 377, 378 (Ind. 2006) (suspending Ouellete for "fail[ing] to act with reasonable diligence and promptness in representing [his] client, ... fail[ing] to keep his client adequately informed, . . . and fail[ing] to make timely responses to the Indiana Supreme Court Disciplinary Commission's [investigation]")).

106. Id. at 491 . 
converted the funds to his own use. ${ }^{107}$ Not until June 2013, when the bankruptcy trustee issued the final report, did the clients become aware of the refund.$^{108}$ After being confronted by the clients, Ouellette issued a check to them on an account other than a trust account. ${ }^{109}$ The check was not honored due to insufficient funds. ${ }^{110}$

A disciplinary investigation was initiated by the Commission, however, Ouellette did not cooperate in the investigation. ${ }^{111}$ This resulted in his law license being suspended in August 2014. ${ }^{112}$ Subsection 10(e) of Rule 23 in the Indiana Rules for Admission to the Bar and the Discipline of Attorneys requires all attorneys to cooperate in any discipline investigation. ${ }^{113}$ Specifically, Subsection 10(e) states:

It shall be the duty of every attorney against whom a grievance is filed under this Section to cooperate with the Commission's investigation, accept service, comply with the provisions of these rules, and when notice is given by registered or certified mail, claim the same in a timely manner either personally or through an authorized agent. ${ }^{114}$

Subsection 10(f) describes the penalty for non-cooperation. ${ }^{115}$ It states that "[a]n attorney who is the subject of an investigation by the Disciplinary Commission may be suspended from the practice of law upon a finding that the attorney has failed to cooperate with the investigation."116 This suspension is administrative and can be quickly rescinded upon the respondent's satisfactory cooperation with the Commission's investigation. ${ }^{17}$

Non-cooperation in a discipline investigation can also serve as the basis for chargeable misconduct. ${ }^{118}$ Rule 8.1(b) of the Indiana Rules of Professional Conduct states that "a lawyer in connection with . . . a disciplinary matter, shall not: . . . (b) . . . knowingly fail to respond to a lawful demand for information from an admissions or disciplinary authority." ${ }^{119}$ In Ouellette's case, he was charged, and found guilty of violating this rule. ${ }^{120}$

107. Id.

108. Id.

109. Id.

110. Id.

111. Id.

112. Id.

113. InD. R. Admis. B. \& Disc. Att'y $23 \S 10(\mathrm{e})$.

114. $I d$.

115. Id. $\S 10(\mathrm{f})$.

116. $I d$.

117. Id. $\S 10(\mathrm{f})(3)$.

118. Id. $\S 10(\mathrm{f})(2)$.

119. Ind. Prof'L ConduCt R. 8.1(b).

120. In re Ouellette, 37 N.E.3d 490, 492 (Ind. 2015). 
Like Hamilton ${ }^{121}$ and Stochel, ${ }^{122}$ Ouellette also failed to answer the complaint and the Commission was granted judgment by default. ${ }^{123}$ Ouellette tried to defend himself after filing deadlines had passed by tendering a belated answer. ${ }^{124}$ His diminished attempt to protect his career was addressed sharply by the court:

Respondent eventually tendered a belated answer at the hearing on the Commission's application for judgment on the complaint, which the hearing officer declined to accept. Given Respondent's refusal to cooperate with the Commission's investigation, his failure to comply with the deadlines imposed under the Admission and Discipline Rules, and his failure to file a petition for review or brief on sanction, we likewise decline to give Respondent's belatedly-tendered answer any effect. ${ }^{125}$

By not depositing the refund check in a trust account, Ouellette violated Rule 1.15(a) of the Indiana Rules of Professional Conduct which requires a lawyer to hold a client's property in trust. ${ }^{126} \mathrm{He}$ also violated Subsection 29(a)(4) of Rule 23 in the Indiana Rules for Admission to the Bar and the Discipline of Attorneys by failing to deposit intact funds received on behalf of a client. ${ }^{127}$

Indiana Rule of Professional Conduct 8.4(b) prohibits a lawyer from "commit[ting] a criminal act that reflects adversely on the lawyer's honesty, trustworthiness, or fitness as a lawyer." ${ }^{228}$ Clearly, Ouellette's unpermitted personal use of his clients' money, as well as his issuance of an insufficient funds check, constituted the criminal acts of conversion and check deception. ${ }^{129}$ Both of these crimes involve dishonesty and exhibit a lack of trustworthiness.

Indiana Rule of Professional Conduct 8.4(c) characterizes as misconduct the "engage[ment] in conduct involving dishonesty, fraud, deceit, or misrepresentation." 130 This separate standard was applied not only to his thievery, but also to his failure to disclose the refund to his clients timely and his issuance to them of an insufficient funds check. ${ }^{131}$ For nearly two and a half years, Ouellette deceived his clients by hiding from them the fact they had received a refund in their bankruptcy proceeding. ${ }^{132} \mathrm{He}$ then fraudulently and dishonestly issued the refund on an insufficient funds check from an account other than a

121. In re Hamilton, 34 N.E.3d 1204, 1205 (Ind. 2015).

122. In re Stochel, 34 N.E.3d 1207, 1208 (Ind. 2015).

123. In re Ouellette, 37 N.E.3d at 491.

124. Id. at $491 \mathrm{n} .1$.

125. Id.

126. Id. at 492 (citing Ind. Prof'L ConduCt R. 1.15(a)).

127. Id. (citing InD. R. ADMIS. B. \& Disc. ATt'y $23 \S 29(\mathrm{a})(4)$ ).

128. Ind. PRof'l Conduct R. 8.4(b).

129. See In re Ouellette, 37 N.E.3d at 491.

130. Ind. Prof'L CONDUCT R. 8.4(c).

131. See In re Ouellette, 37 N.E.3d at 491-92.

132. Id. at 491 . 
lawyer trust account. ${ }^{133}$

As in the other recent cases of client theft, the court issued a stern warning to lawyers who steal from clients: "Misappropriation of client funds is a grave transgression. It demonstrates a conscious desire to accomplish an unlawful act, denotes a lack of virtually all personal characteristics we deem important to law practice, threatens to bring significant misfortune on the unsuspecting client and severely impugns the integrity of the profession."134

\section{IN RE PHILPOT}

Attorney Thomas R. Philpot formerly served as the elected Lake County, Indiana Clerk of Courts. ${ }^{135}$ In 2012, he was adjudicated guilty on two felony counts of mail fraud and one felony count of theft from a federally funded program. ${ }^{136}$ The convictions occurred in the U.S. District Court for the Northern District of Indiana ${ }^{137}$ His appeal of the convictions was unsuccessful. ${ }^{138}$

Philpot's crimes arose from his payment to himself of a salary bonus from the child support incentive money awarded to the County Clerk's Office by the federal government under Title IV-D of the Social Security Act (commonly known as "4-D funds"). ${ }^{139}$ It is interesting 4-D incentive funds are permitted to be used to supplement salaries for those persons involved in the child support collection and enforcement process. However, the awarding of a supplemental salary must be approved through the County fiscal body's budget and appropriation process. ${ }^{140}$ Philpot by-passed this important step. ${ }^{141} \mathrm{He}$ essentially resorted to self-help in awarding a bonus to himself. ${ }^{142}$

Philpot and the Commission stipulated to most of the facts supporting the misconduct, although the parties disagreed on the exact results of applying the law to the facts. ${ }^{143}$ The parties also agreed the criminal acts were a violation of Indiana Rules of Professional Conduct 8.4(b) which prohibits a lawyer from committing a criminal act that reflects adversely on the lawyer's honesty, trustworthiness, or fitness as a lawyer ${ }^{144}$ Furthermore, the parties conditionally agreed a four year suspension of Philpot's law license would be an appropriate

133. Id.

134. Id. at 492 (citing In re Hill, 655 N.E.2d 343, 345 (Ind. 1995)).

135. United States v. Philpot, 733 F.3d 734, 738 (7th Cir. 2013).

136. Id.

137. Id. at 741 .

138. $I d$.

139. Id. at 738-39; 42 U.S.C. $\S 658$ a (2012).

140. Philpot, 733 F.3d at 738 (quoting IND. CoDE $\S 31-25-4-23$ (c) (2013)) (“"A]mounts received as incentive payments may not, without the approval of the county fiscal body, be used to increase or supplement the salary of an elected official.").

141. Id. at 738-39.

142. Id. at 739 .

143. Id. at 742-45; In re Philpot, 31 N.E.3d 468, 468-69 (Ind. 2015).

144. In re Philpot, 31 N.E.3d at 469. 
penalty and no facts in aggravation were cited to the court. ${ }^{145}$ Facts in mitigation that led to the agreement between the parties were: (1) Philpot's lack of prior lawyer discipline; (2) his cooperation with the Commission's investigation including his prompt self-report of his conviction to the Commission; and (3) his repayment with interest of the misappropriated money before the filing of his federal criminal charges. ${ }^{146}$

The court accepted the conditional agreement on a narrow vote of 3-2. ${ }^{147}$ Chief Justice Rush and Justice Dickson dissented. ${ }^{148}$ It was their belief Philpot should have been disbarred. ${ }^{149}$ Also, the court found its own aggravator for sanction. ${ }^{150}$ The court found as an elected official, Philpot betrayed the public trust. ${ }^{151}$ This betrayal violated his oath of office and also his oath as an attorney. ${ }^{152}$

The Oath of Attorneys is codified as the Indiana Rule for Admission to the Bar and the Discipline of Attorneys $22 .{ }^{153}$ Every lawyer must take and subscribe to the Oath of Attorneys upon being admitted to practice law. ${ }^{154}$ Violation of the attorney oath is actionable as misconduct, but it is infrequently used as a charged violation. ${ }^{155}$ Arguments the Oath is vague, ${ }^{156}$ as well as aspirational rather than doctrinal, have steered lawyer discipline authorities away from using the Oath as a basis for instituting an ethics prosecution. It is much more legally efficient to use the Rules of Professional Conduct as the foundation and standards for ethical misconduct.

As previously referenced, the court went beyond what the parties submitted as the terms of their conditional agreement and sua sponte inserted the attorney oath violation as a fact in aggravation of the sanction. It is important to note the oath violation was not inserted as a substantive rule violation, but instead the oath was incorporated into the rule..$^{157}$ There is precedent for the court taking this type of action. ${ }^{158}$ In at least three cases the court, used the oath as a basis to

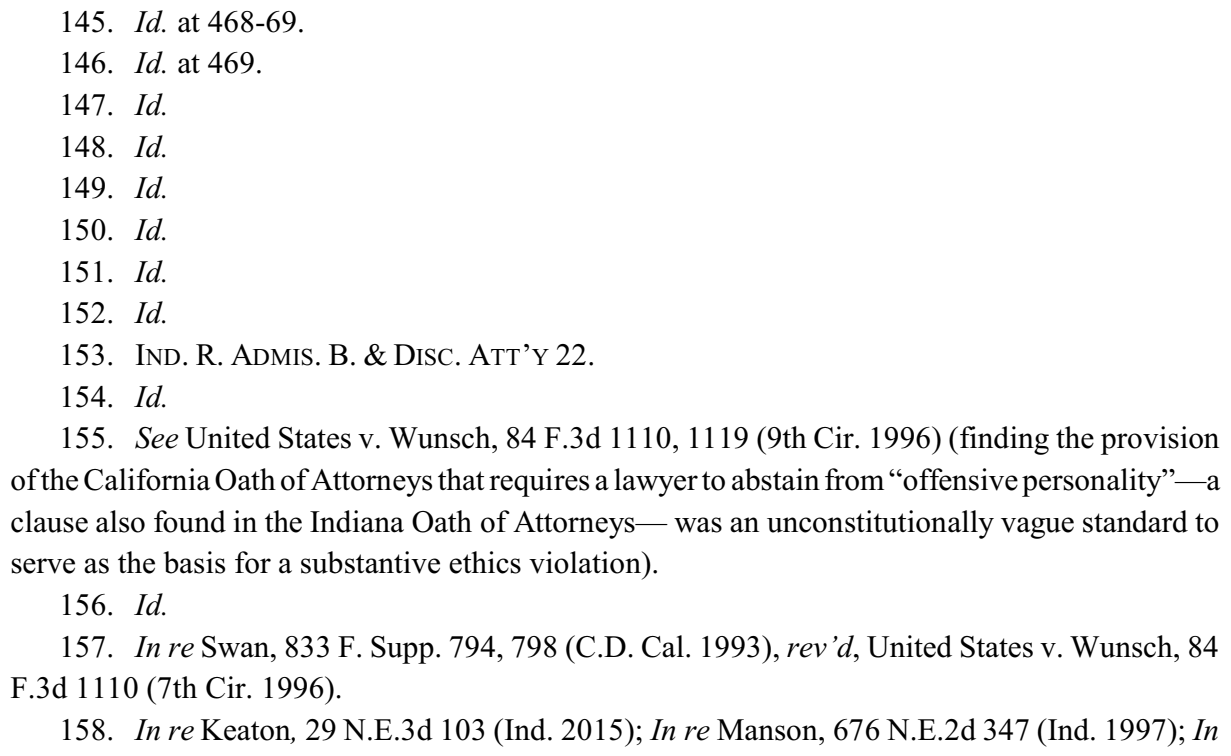


aggravate a sanction upon a finding of misconduct. ${ }^{159}$

In the case of In re Burns, the lawyer made several threatening comments to an opposing party during a recess of a pre-trial conference. ${ }^{160}$ The recording equipment continued to operate during the recess. ${ }^{161}$ Burns told the opposing party,

I'm going to come over to your house and I'm going to hit you in the head with a baseball bat ... Now, that's my promise to you, right here on the record. I'm going to come over to your house and beat you half to death with a baseball bat. ${ }^{162}$

He also told the opposing party, "you're going to go out of here in a hospital van. Don't press your luck. . . don't press your luck. Because you're not going to like me if I'm angry. You won't walk away from it, I guarantee you."163

The court found as a sentence aggravator Burns' conduct was contrary to the Oath of Attorneys offensive personality clause. ${ }^{164}$ The court imposed a thirty (30) days suspension for the misconduct. ${ }^{165}$

The court also found an Oath of Attorneys violation as a sanction aggravator in the case of In re Manson. ${ }^{166}$ Attorney Manson engaged in sexual relations with a client in the courtroom of the Naval Legal Service Office Detachment in Kings Bay, Georgia. ${ }^{167}$ Manson was an Indiana lawyer and a lieutenant in the Judge Advocate General's Corps of the U.S. Naval Reserve. ${ }^{168}$ The court found the oath requirement that a lawyer "maintain the respect due to courts" 169 was violated. The result was a six months suspension with automatic reinstatement of his license. ${ }^{170}$

The case of In re Keaton, ${ }^{171}$ previously discussed in this article, also led the court to find as a sanction aggravator that Keaton's conduct was not in conformity to the standards imposed by the Oath of Attorneys. ${ }^{172}$

In two other cases, the court found a lawyer's misconduct served as a

re Burns, 657 N.E.2d 738 (Ind. 1995).

159. In re Keaton, 29 N.E.3d at 103; In re Manson, 676 N.E.2d at 347; In re Burns, 657 N.E.2d at 738 .

160. In re Burns, 657 N.E.2d at 739 .

161. Id.

162. Id.

163. Id.

164. Id. at 740 .

165. Id.

166. In re Manson, 676 N.E.2d 347 (Ind. 1997).

167. Id. at 348 .

168. Id.

169. Id. at 348; IND. R. Admis. B. \& Disc. ATt'y 22.

170. In re Manson, 676 N.E.2d at 348.

171. In re Keaton, 29 N.E.3d 103 (Ind. 2015).

172. Id. at 110 . 
substantive violation of the oath. ${ }^{173}$ However, both of these cases were submitted to the court on a conditional agreement for discipline. ${ }^{174}$ Because both lawyers consented to their misconduct being a violation of the offensive personality clause of the Oath of Attorneys, the court was not faced with having to interpret whether the clause had constitutional impediments. ${ }^{175}$

\section{IN RE SANDERSON}

Robert S. Sanderson was a lawyer licensed in Missouri and Indiana. ${ }^{176}$ His practice was located in St. Louis, Missouri. ${ }^{177}$ Over the course of seven years, he crossed over the Mississippi River and practiced regularly in Illinois courts. ${ }^{178}$ It was estimated he entered an appearance in over 3000 Illinois legal matters during that time. ${ }^{179}$ Sanderson victimized an unknowing Illinois female lawyer by using her attorney number on all of the Illinois pleadings and papers. ${ }^{180}$

The Illinois Supreme Court completed disciplinary action against Sanderson and eventually disbarred him despite not being licensed in Illinois. ${ }^{181}$ One is probably asking how can Illinois take action against a lawyer's license if the lawyer is not licensed in that state? A lawyer not licensed in Illinois consents to the licensing discipline jurisdiction of that state when he or she chooses to practice law there. ${ }^{182}$ Illinois Supreme Court Rule 779 states,

Unauthorized practice of law proceedings authorized by the Inquiry

Board against an Illinois attorney who is suspended or against a lawyer licensed in another jurisdiction in the United States shall be instituted by the Administrator by the filing of a disciplinary complaint before the Hearing Board, and the hearing and review procedure shall be governed by Rule $753 .{ }^{183}$

Indiana Rules for Admission to the Bar and the Discipline of Attorneys 23(1) is similar in establishing discipline jurisdiction over a lawyer not licensed in Indiana.${ }^{184}$ It states, "[t]he Supreme Court has exclusive jurisdiction of all cases

173. See In re Coons, 751 N.E.2d 678, 678 (Ind. 2001) (noting the lawyer inquired into the sexual practices of his client, asked her if she had ever thought about becoming a prostitute, asked her to wear revealing clothes, and asked if he could see her breasts); see also In re May, 992 N.E.2d 684, 684-85 (Ind. 2013).

174. See In re Coons, 751 N.E.2d at 678; see also In re May, 992 N.E.2d at 684-85.

175. See In re Coons, 751 N.E.2d at 678; see also In re May, 992 N.E.2d at 684-85.

176. Grogan, supra note 3.

177. $I d$.

178. Id.

179. Id.

180. Id.

181. In re Sanderson, 39 N.E.3d 375, 375 (Ind. 2015).

182. ILl. Sup. CT. R. 779.

183. Id.

184. InD. R. ADMis. B. \& DisC. ATt'y $23 \S 1$. 
in which an attorney who is admitted to the bar of this Court or who practices law in this State (hereinafter referred to as "attorney") is charged with misconduct." 185

Since Sanderson was licensed in Indiana, he became subject to reciprocal discipline in Indiana under the Indiana Rule for Admission to the Bar and the Discipline of Attorneys 23(2)(b). ${ }^{186}$ The rule states:

If an attorney admitted to practice in this State who is also admitted to practice in any other state should be disbarred or suspended by the proper authority of such other state, such disbarment or suspension shall constitute sufficient grounds for disbarment or suspension of said attorney in this State. ${ }^{187}$

Indiana Rule for Admission to the Bar and the Discipline of Attorneys 23(28)(c) limits the reciprocal action in Indiana to the following legal issues:

(1) The procedure was so lacking in notice or opportunity to be heard as to constitute a deprivation of due process;

(2) There was such infirmity of proof establishing the misconduct as to give rise to the clear conviction that the Court could not, consistent with its duty, accept as final the conclusion on that subject;

(3) The imposition of suspension by the Court would be inconsistent with standards governing sanctions in this rule or would result in grave injustice; or

(4) The misconduct established warrants substantially different discipline in this state. ${ }^{188}$

The rule further states:

If this Court determines that any of those elements exists, this Court shall enter such other order of discipline as it deems appropriate. The burden is on the party seeking different discipline in this state to demonstrate that the imposition of the same discipline is unwarranted. ${ }^{189}$

Lastly, the reciprocal discipline rule prohibits collateral attack on the facts underlying the misconduct in the other jurisdiction. ${ }^{190}$ It firmly establishes a final adjudication of attorney misconduct in another jurisdiction is conclusive for determining misconduct in Indiana. ${ }^{191}$

Illinois imposed disbarment on Sanderson. ${ }^{192}$ However, as pointed out in the

185. Id. (emphasis added).

186. Id. § 2(b).

187. Id.

188. Id. $\S 28(\mathrm{c})$.

189. Id.

190. Id.

191. Id. $§ 28(\mathrm{~d})$.

192. In re Sanderson, 39 N.E.3d 375, 375 (Ind. 2015). 
opening of this Article, disbarment in Illinois is not permanent. ${ }^{193}$ Sanderson is eligible to seek reinstatement in Illinois in five years even though he never had an Illinois license with which to begin. ${ }^{194}$ However, under Indiana Rule for Admission to the Bar and the Discipline of Attorneys 23(28)(c)(3), a reciprocal disbarment would be permanent with no opportunity to seek reinstatement. ${ }^{195} \mathrm{An}$ Indiana disbarment would be inconsistent with an Illinois disbarment because they are not mirror images of each other. ${ }^{196}$ The Indiana Supreme Court addressed this by imposing an indefinite suspension on Sanderson. ${ }^{197}$ The court stated Sanderson's law license was "suspended indefinitely from the practice of law in this state as of the date of this order . . . If Respondent is granted reinstatement in Illinois, Respondent may file a 'Motion for Reinstatement' pursuant to and in full compliance with Admission and Discipline Rule 23(28)(e) ...." 198

Even though the act of imposing discipline was reciprocal (i.e. the adjudication of misconduct in Illinois was reciprocated in Indiana), the sanction was not. Or was it? Another interpretation of the Indiana Supreme Court's decision could be as follows: a disbarment in Illinois is actually a suspension since there is a chance of reinstatement. ${ }^{199}$ However, the Illinois reinstatement is not automatic. ${ }^{200}$ There is no guarantee of reinstatement being granted. ${ }^{201}$ The uncertainty of Illinois reinstatement makes the license suspension indefinite. ${ }^{202}$ Therefore, the Indiana Supreme Court reciprocated with a suspension for an indefinite period. ${ }^{203}$ No matter the interpretation, Sanderson's prospects of first getting reinstated in a jurisdiction where he never held a license to begin with are fairly bleak.

\section{CONCLUSION}

The Indiana Supreme Court disbarred four lawyers in 2015. ${ }^{204}$ If expanded to include 2014, the number of disbarments climbs to eight. ${ }^{205}$ In the ten year

193. ILl. Sup. CT. R. 760(a), 767(a).

194. Id.

195. Ind. R. Admis. B. \& Disc. AtT’y $23 \S 28(\mathrm{c})(3)$.

196. Compare Ill. Sup. Ct. R. 760(a), 767(a), with Ind. R. Admis. B. \& DisC. AtT'Y $23 \S$ 28(c)(3).

197. In re Sanderson, 39 N.E.3d at 375.

198. Id.

199. Compare Ill. Sup. Ct. R. 760(a), 767(a), with Ind. R. Admis. B. \& Disc. AtT'Y $23 \S$ 28(c)(3).

200. ILl. Sup. CT. R. 760(a), 767(a).

201. Id.

202. Id.

203. In re Sanderson, 39 N.E.3d at 375.

204. Discipline, IND. LAw., http://www.theindianalawyer.com/discipline [http://perma.cc/NK7A-PUJM] (last visited May 13, 2016).

205. Disciplinary Commission Annual Reports, Ind. JUd. BRANCH, 
span of July 2004 to July 2013, a total of eight disbarments occurred. ${ }^{206}$ In 2015, the court established a firm disciplinary position on a lawyer who engaged in personal misconduct outside his practice of law. The court also took a similar firm stance on lawyers stealing from monies held in trust. A lawyer who held an elected public office and misappropriated public funds had his law license tied to his oath of office and his Oath of Attorneys. The violation of those oaths served to aggravate his license sanction with two justices voting for disbarment.

The practice of law is an honorable profession. Those who bring it dishonor and damage its honor to a great degree are susceptible to a permanent removal from the profession.

http://www.in.gov/judiciary/discipline/2336.htm, [http://perma.cc/R9U2-SKX4] (last visited May 13, 2016).

206. $I d$. 